\title{
YOUR MONEY OR YOUR LIFESTYLE!: EMPLOYERS' EFFORTS TO CONTAIN HEALTHCARE COSTS - LIFESTYLE DisCRIMINATION AgAINST DEPENDENTS OF EMPLOYEES?
}

\author{
Brendan W. Miller*
}

TABLE OF CONTENTS

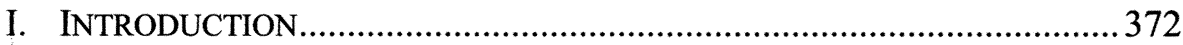

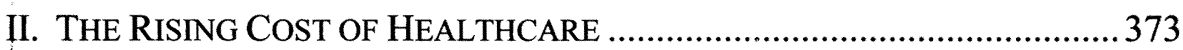

A. Trends in Employment-Related Health Insurance Costs............ 373

B. Effect of Rising Healthcare Costs on Employers......................... 374

C. Effect of Rising Healthcare Costs on Employees ..........................375

III. EMPLOYER RESPONSES TO RISING HEALTHCARE COSTS ......................376

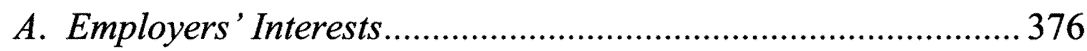

B. Make Employees Pay for Their "Vices" or Do Not Hire

Them in the First Place ............................................................. 376

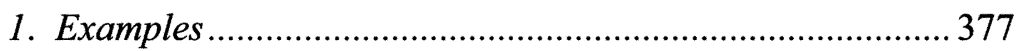

a. Clarian Health Partners................................................ 377

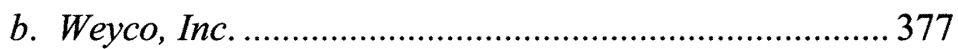

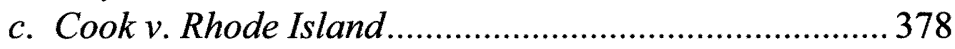

2. Requiring Employees to Bear the Costs Versus Not

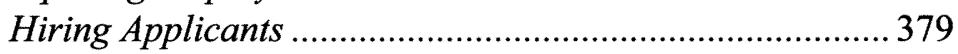

C. Spouses and Other Dependents of Employees .......................... 379

IV. DISTINCTION BETWEEN THE EMPLOYEE AND THE EMPLOYEE'S

SPOUSE OR DEPENDENT, WITH RESPECT TO HEALTH

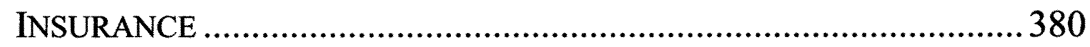

A. The Nature of Employer-Sponsored Health Insurance ….......... 380

B. Third Party Beneficiary Law................................................. 382

V. EMPLOYER CONTROL OF OFF-DUTY CONDUCT - LIFESTYLE

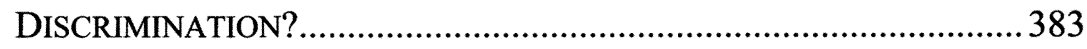

A. Employer Control of Off-Duty Employee Conduct...................... 383

B. Lifestyle Discrimination Concerns..............................................385

C. Extending Restrictions on Off-Duty Conduct to Spouses and Other Dependents of Employees .......................................... 387

VI. PRoteCtIONS AgAINST LIFESTYLE DISCRIMINATION .........................387

A. Protections for Employees........................................................ 388

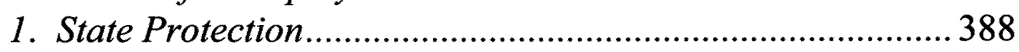

2. Federal Protection ………………………………............. 389

* J.D. Candidate, 2007, Indiana University School of Law - Indianapolis; B.S., 1996, Manchester College; M.S.W., 1998, Indiana University. 
a. Employee Retirement Income Security Act of 1974 ("ERISA")

b. Health Insurance Portability and Accountability Act of 1996 ("HIPAA") ................................................. 390

c. Proposed federal legislation .............................................393

B. Protection for Employees' Spouses and Dependents ..................396

VII. ALTERNATIVES FOR HEALTHCARE COST CONTAINMENT .....................397

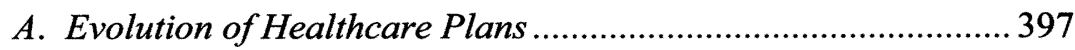

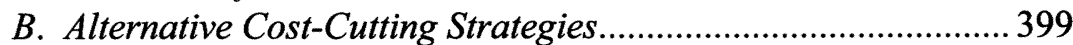

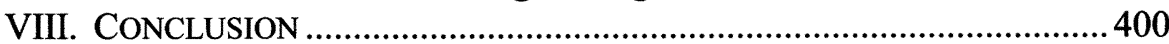

\section{INTRODUCTION}

Jack and Jill are married and have a daughter named Sally. Jack works for the Smith Agency, which provides health insurance coverage for employees and their dependents. Jack, Jill, and Sally are enrolled in the health plan. To encourage healthy lifestyles, the Smith Agency instituted a wellness program entitled "Healthy Living." The program includes an array of smoking cessation activities consisting of pamphlets, classes, and support groups. To bolster the efficacy of the smoking cessation component, the Smith Agency recently instituted a no-smoking policy under which employees will be subjected to periodic screenings for the presence of nicotine in their systems. Employees testing positive for nicotine will be asked to pay a higher premium for their healthcare coverage. Having realized some healthcare expenditure savings since instituting the nicotine screenings, the Smith Agency is now planning to expand the program to encompass non-employees covered under their health plan.

Faced with the reality of high healthcare costs, employers continue to seek creative ways to curb those costs. The strategy deployed by the Smith Agency is not dissimilar from strategies being explored and used by many employers. If these strategies are effective for lowering healthcare costs for the employer and for those employees and other beneficiaries who do not engage in "risky" or "unhealthy" behaviors, don't they just make good business sense? What if employer policies extend to tracking less stigmatized vices than nicotine? If the Smith Agency were to begin testing to ensure Jill was not consuming "unhealthy" levels of caffeine and to make sure Sally's intake of snacks did not include too many sweets or salty treats-would that be going too far?

At what point do the legitimate business interests of the employer give way to concerns about invasion of privacy rights of the employees' dependents covered under the employer's health plan?

This Note addresses these issues, first, by providing an overview of the rising costs of healthcare and the effect it has on employers and employees. Next, notable responses employers have to rising costs are discussed; including not hiring applicants with unhealthy habits or risky behaviors, or making these 
employees pay for their habits or behaviors by shifting more of the cost of healthcare to these employees. The following section compares the status of employees with the status of spouses and other dependents of employees covered under the same employer health plan to determine how, or if, the two groups are distinguished in any legally significant way with respect to their rights under an employer-sponsored health plan. Then, the notion of lifestyle discrimination that results from employers controlling employees' off-duty behaviors or habits that may be risky or unhealthy is examined for its applicability to spouses and other dependents of employees. Additionally, state and federal protections against lifestyle discrimination are discussed. Finally, this note addresses alternative strategies for employers to cut healthcare costs.

\section{THE RISING COST OF HEALTHCARE}

National spending on healthcare continues to rise. Nationwide healthcare spending amounted to two trillion dollars in 2005; this amount equates to approximately $\$ 6700$ per person $^{1}$ and represents nearly one-sixth of the gross domestic product. ${ }^{2}$ Total health expenditures in 2005 rose by $6.9 \%$, or twice the rate of inflation. ${ }^{3}$ Spending on healthcare is expected to continue to rise over the next ten years reaching four trillion dollars in 2015, or twenty percent of the gross domestic product. $^{4}$

\section{A. Trends in Employment-Related Health Insurance Costs}

About 158 million non-elderly Americans are covered by employersponsored health insurance. ${ }^{5}$ In 2007 , sixty percent of firms offered health benefits to at least some of their employees. ${ }^{6}$ The percentage of firms offering health benefits has fallen since 2000 , when sixty-nine percent of firms offered benefits. $^{7}$

Health insurance premiums are on the rise, though at a slower pace than in recent years. In the spring of 2007, premiums for employer-sponsored health insurance had risen by $6.1 \%$ over the previous year, a decrease from the $7.7 \%$

1. Nat. Coal. ON Health Care, Health Insurance Cost 1 (2006) [hereinafter Nat. COAL. ON HEALTH CARE], available at http://www.nchc.org/facts/2007\%20updates/cost.pdf (citing A. Catlin et al., National Health Spending in 2005, 26 HEALTH AFF. 1, 142-53 (2006)).

2. Id.

3. Id. (citing Catlin et al., supra note 1, at 142-53).

4. Id. (citing C. Borger et al., Health Spending Projections Through 2015: Changes on the Horizon, WeB EXClusive, W61 Health AfF. 22, (2006)).

5. The Kaiser Fam. Found. \& Health Res. \& Educ. Tr., EMPloyer Health Benefits: 2007 SUMMARY OF FINDINGS 1 (2007) (citing Kaiser Comm'n on Medicaid \& the Uninsured, Health Insurance Coverage in America, DATA UPDATE (Kaiser Fam. Found., Menlo Park, C.A.), 2005), available at http://www.kff.org/insurance/7672/upload/Summary-of-Findings-EHBS2007.pdf.

6. Id. at 4.

7. Id. 
increase in $2006 .^{8}$ The 2007 increase is the lowest rate of growth since 1999, when premiums increased by $5.3 \%{ }^{9}$ The changes in premium rates are experienced differently by different workers, though. In 2007, forty-six percent of covered workers worked for firms where premiums increased five percent or less, while ten percent of covered workers worked for firms where premiums increased more than fifteen percent. ${ }^{10}$ Though the rate by which premiums have increased has slowed, premiums far outpaced overall inflation (2.6\%) and wage gains $(3.8 \%) .{ }^{11}$

\section{B. Effect of Rising Healthcare Costs on Employers}

Rising healthcare costs have had a profound effect upon employers. "Health insurance expenses are the fastest growing cost component for employers. Unless something changes dramatically, health insurance costs will overtake profits by 2008." ${ }^{12}$ The increases in healthcare spending over the last five years has cut into operating margins and reduced the capacity of businesses to grow through investment in research, capital spending, product development, and marketing. ${ }^{13}$ High health insurance costs hinder job growth by making it more expensive for companies to add new employees or retain their existing employees. ${ }^{14}$ Between 2000 and 2005, employers' health insurance premiums increased about seventy-three percent, but wages increased only fifteen percent during the same period. ${ }^{15}$ Consequently, American businesses have a competitive disadvantage with foreign competitors that have operations in countries with universal health insurance programs and slower healthcare cost inflation. ${ }^{16}$ In response, some American businesses have joined together, on a national basis, to develop solutions to the problem of rising healthcare costs. ${ }^{17}$

Small businesses are disparately affected by rising healthcare costs. Most midsize and large businesses offer health benefits, but thirty-eight percent of workers are employed in smaller businesses, where less than two-thirds of firms

8. Id. at 1 .

9. Id.

10. Id.

11. Id.

12. NAT. Coal. ON Health CARE, supra note 1.

13. Nat. Coal. on Health Care, The Impact of Rising Health Costs on the ECONOMY: EFFECTS ON BUSINESS OPERATIONS 2-3 (2006), available at http://www.nchc.org /facts/Economy/Costs-Business\%20Operations.pdf.

14. Id. (citing Henry J. Kaiser Fam. Found., Employee Health Benefits: 2005 AnN. SURVEY (2005), available at http://www.kff.org/insurance (last visited Feb. 20, 2008)).

15. Id.

16. Id. General Motors adds over $\$ 1500$ to every car and truck made because of healthcare costs. Julie Appleby \& Sharon Silke Carly, Ailing GM Looks to Scale Back Generous Health Benefits, USA TODAY, June 24, 2005, at B1.

17. See generally Inst. On Health Care Costs \& Solutions, National Business GrouP ON HEALTH, available at $\mathrm{http} / / / \mathrm{www}$.businessgrouphealth.org/healthcarecosts/institute .cfm (on file with the author). 
offer health benefits to their workers. ${ }^{18}$ Since 2000 , high health insurance costs have resulted in 266,000 firms - most of which employ fewer than twenty-five workers - no longer offering health insurance coverage. ${ }^{19}$ Compelled by premium increases, many small firms which do continue to offer health insurance have shifted a greater portion of these costs to their employees. ${ }^{20}$ "Employees in small firms who have family coverage contributed nearly $\$ 1100$ more a year for premiums than their counterparts in larger firms."21 Many low-wage workers have elected to do without coverage due to the high costs. ${ }^{22}$

\section{Effect of Rising Healthcare Costs on Employees}

High health insurance premiums have left millions of workers with no health insurance coverage "because many employers cannot afford to provide health benefits." ${ }^{, 3}$ Even when employers provide health insurance, many working families cannot afford the employee's portion of the premiums. "Workers on average pay 27 percent of the premium. ${ }^{25}$ The compounding effect of high health insurance costs means that wage growth lags, and employees' gains in take-home pay are substantially reduced. ${ }^{26}$

Clearly, the magnitude of healthcare costs is impacting employers and employees collectively and as individual groups. The nature of the employment relationship is affected by the trend of rising costs. Therefore, employers have been and will continue to develop responses to healthcare costs to maximize their interests.

18. See Nat. Coal. on Health Care, The Impact of Rising Health Costs on the ECONOMY: EFFECTS ON SMALl BUSINESSES 1 (2006), available at http://www.nchc.org/facts/ Economy/Costs-Small\%20Businesses.pdf(citing U.S. GeN. ACCOUNTABILITY OFFICE, PRIVATE Health Insurance: Small Employers Continue to Face Challenges in Providing COVERAGE (2001), available at http://www.gao.gov/new items/do28.pdf; HENRY J. KAISER FAM. Found., The Uninsured: A Primer, Key Facts About Americans Without Health INSURANCE (2006), available at http://www.kff.org/uninsured (last visited Mar. 14, 2008)).

19. Id. at 2-3 (citing HeNRY J. KAISER FAM. Found., EMPLOYEe HeAlth BENEFITS: 2005 ANN. SURVEY (2005), available at http://www.kff.org/insurance (last visited Mar. 14, 2008)).

20. Id.

21. Id.

22. Id. Deductibles paid by small firm employees are also significantly higher than deductibles paid by larger firm employees; compared to large firm employees, small firm employees enrolled in preferred provider organization plans pay deductibles that are one-hundred percent higher when using in-network providers and sixty percent higher for out-of-network providers. Id.

23. Nat. Coal. on HealthCare, The Impact of Rising Health Costs on the Economy - EFFECTS ON WORKERS AND FAMILIES 1 (2006), available at http://www.nchc.org/facts/ Economy/Costs-Workers\&Families.pdf.

24. Id. at 2 (citing Henry J. Kaiser Fam. Found., Employee Health Benefits: 2005 ANN. SURVEY (2005), available at http://www.kff.org/insurance (last visited Mar. 14, 2008)).

25. Id.

26. Id. (citing COUNCIL OF ECON. AdVISORS, ECON. UPDATE, ACHIEVEMENTS, AND OBJECTIVES FOR THE FUTURE - A WHITE PAPER, (2005)). 


\section{EMPLOYER RESPONSES TO RISING HEALTHCARE COSTS}

\section{A. Employers' Interests}

Given the rising costs of health insurance, employers have incentive to encourage healthy lifestyles in their employees. Lost hours of work due to sickness or other reasons take a toll on the employer's bottom line. Moreover, some employees are more likely to cause extra expenses for their employers (e.g., employees needing special accommodations related to disabilities or special work hours). ${ }^{27}$ Even employees who have legitimate reasons for being absent from work can, however, cause productivity problems for employers. Indeed, if the absence is caused by illness or injury claims can be brought against the employer's health plan as well as claims for paid sick leave. ${ }^{28}$ Additionally, employee conduct away from the workplace can also impact the workplace. Thus, even activities employees carry out during the normal course of everyday living - eating, drinking, smoking, driving, etc.-may conflict with the interests of the employer. ${ }^{29}$

\section{B. Make Employees Pay for Their "Vices" or Do Not Hire Them in the First Place}

Employers are increasingly seeking to limit their healthcare cost burdens by adjusting their hiring practices and discouraging unhealthy habits. ${ }^{30}$ For example, employers have implemented non-smoker hiring policies citing the benefits of limiting healthcare costs, banning workplace smoking, and avoiding the hiring of people who are likely to be absent more than average. ${ }^{31}$ Citing concern for higher healthcare costs, some employers may even use candidates' private eating habits as a factor to disqualify them from employment. ${ }^{32}$

27. Stephen D. Sugarman, "Lifestyle" Discrimination in Employment, 24 BERKELEY J. EMP. \& LAB. L. 377,383 (2003).

28. Id.

29. Id. at 391.

30. See, e.g., Joe Robinson, Light Up, Lose Your Job, L.A. TIMES, Feb. 19, 2006, at M3; Shaunti Feldhahn \& Diane Glass, Do Companies Have the Right to Dictate Workers' Health Habits?, Buffalo News, Feb. 12, 2006; Cami Reister, Clearing the Air: Companies Go to New Lengths to Stomp Out Tobacco Use, THE GRAND RAPIDS PRESS, Sept. 25, 2005, at H1; Shirleen Holt, Companies Increasingly Saying Smokers Need Not Apply, SEATTLE TIMES, Oct. 10, 2004.

31. Sugarman, supra note 27, at 391.

32. Id. at 392 . 


\section{Examples ${ }^{33}$}

Description of some particular cases is helpful to illustrate the types of policies being adopted by employers in response to rising healthcare costs:

\section{a. Clarian Health Partners}

Clarian Health Partners, an Indiana-based hospital chain, made national headlines in 2007 when it announced a policy aimed at trimming both healthcare costs and the prevalence of overweight workers within its ranks. ${ }^{34}$ Other employers have adopted policies to create incentives for healthy behavior or make overweight employees pay if they do not lose weight. "In one of the boldest moves yet, [Clarian Health Partners] said it decided on the stick rather than the carrot." ${ }^{, 36}$ According to its announced policy, beginning in 2009, Clarian Health Partners will charge employees up to thirty dollars every other week unless they meet weight, cholesterol and blood-pressure guidelines set by the company and deemed to be healthy. ${ }^{37}$

Several weeks after the announcement, however, Clarian Health Partners made some concessions to place more emphasis on the carrot and less on the stick. $^{38}$ After listening to feedback from employees, the company now plans to “offer incentives on employees' health insurance premiums for meeting certain parameters for known health risks including smoking, high body mass index (BMI), blood pressure and cholesterol.",39

\section{b. Weyco, Inc.}

Weyco, Inc. is a Michigan-based company. ${ }^{40}$ Weyco's president, Howard Weyers, was concerned about healthcare costs related to smoking. ${ }^{41}$ As a result, prior to 2005 Weyers informed his employees they would be charged a

33. Limitations on the ability of employers to implement such policies vary by jurisdiction. See text accompanying notes 124-81.

34. Daniel Costello, Workers are Told to Shape Up or Pay Up - To Hold Down Medical Costs, Some Firms are Penalizing Workers Who are Overweight or Don't Meet Health Guidelines, L.A. TiMES, July 29, 2007, at A1.

35. Id.

36. Id.

37. Id.

38. Raquel Bahamonde, Employees Call for Change; Clarian Listens, INSIDE IND. Bus., Sept. 13, 2007, available at $\mathrm{http}: / / \mathrm{www}$.insideindianabusiness.com/newsitem.asp?id=25435\# middle (last visited Mar. 14, 2008).

39. Id.

40. NAT. WORKRIGHTS INST., LIFESTYLE DisCRIMINATION: EMPLOYER CONTROL OF LEGAL OFF DUTY EMPLOYEE ACTIVITIES 5 (2006), available at http://www.workrights.org/issue_life style/ldbrief2.pdf.

41. Id. 
fifty dollar smoking fee; the fee would be waived for employees who passed a nicotine test or, if they failed, agreed to take a smoking cessation class. ${ }^{42}$ With assistance from a company-sponsored smoking counselor, about twenty employees successfully quit smoking. ${ }^{43}$ Weyers' policy change included an ultimatum that employees must quit smoking by January $1,2005 .{ }^{44}$ After that date, Weyco began mandatory testing for nicotine; employees who failed the test would be fired. ${ }^{45}$

Weyco's smoking policy raises issues regarding both an employer's ability to discriminate with respect to an employee's lifestyle choices and the privacy rights of employees. ${ }^{46}$ "With new policies such as Weyco's, which allow an employer to test for the existence of legal products in an employee's system-in Weyco's case, tobacco- society must ask itself how much discrimination on the basis of lifestyle is it willing to tolerate from employers?"47

\section{c. Cook v. Rhode Island}

Bonnie Cook worked as an attendant at a facility for mentally disabled persons from 1978 to 1980 , and again from 1981 to $1986 .{ }^{48}$ Both times she departed voluntarily without blemishes on her work record. ${ }^{49}$ In 1988, Cook reapplied for an identical position. ${ }^{50}$ At that time, "she stood 5'2" tall and weighed over 320 pounds." 51 During a routine pre-hire physical, a facility nurse concluded that, though Cook was morbidly obese, her condition did not impinge upon her ability to do the job. ${ }^{52}$ Although Cook passed the physical examination, the facility claimed her obesity would limit her ability to move patients in case of emergency and put her at greater risk of developing serious illness; the facility refused to hire Cook. ${ }^{53}$ Cook won her suit against the facility under a claim that the facility violated the prohibition against handicap discrimination contained in the Rehabilitation Act of $1973 .^{54}$

While these examples do not exhaustively cover the array of employer responses addressing high healthcare costs, they demonstrate two of the main strategies available to and utilized by employers: (1) avoidance of cost (by not hiring employment candidates who engage in risky or unhealthy behaviors);

42. Id. at 6 .

43. Id.

44. Id.

45. Id.

46. Ann L. Rives, Note, You're Not the Boss of Me: A Call for Federal Lifestyle Discrimination Legislation, 74 GEO. WASH. L. REV. 553, 554 (2006).

47. Id.

48. Cook v. Rhode Island, 10 F.3d 17, 20-21 (1st Cir. 1993).

49. Id.

50. Id.

51. Id.

52. Id.

53. Id.

54. Cook v. Rhode Island, 10 F.3d 17, 20-21 (1st Cir. 1993). 
and (2) limiting cost (by shifting a portion of the higher costs to those employees who choose to engage in risky or unhealthy behaviors).

\section{Requiring Employees to Bear the Costs Versus Not Hiring Applicants}

Some argue that requiring employees with unhealthy lifestyles to bear the increased health costs associated with their behaviors (e.g., charging employees a higher premium) is preferable to refusing to hire them as employees. ${ }^{55}$ This solution still arguably subjects the employee to an invasion of privacy. ${ }^{56} \mathrm{~A}$ smoker, for example, "would still be required to disclose her status as a smoker in order to gain employment." employees to a slippery slope by which employers may use other risky behaviors or activities as cause for terminating or reducing the employee's health insurance. ${ }^{58}$ An employer interested in reducing healthcare costs would have incentive to discover employees' unhealthy habits to gain the benefit of continuing work product from the employee while reducing healthcare costs. ${ }^{59}$

\section{Spouses and Other Dependents of Employees}

As employers look for strategies to reduce healthcare costs, costs associated with non-employees covered under the employer's healthcare plan constitute an area of potential savings. Weyco, Inc. has already expressed interest in extending its cost-cutting strategies to spouses of its employees. ${ }^{60}$ For example, Weyco's president wants to extend the employee smoking ban to spouses of his employees. ${ }^{61}$ Health-testing of spouses would accompany the smoking ban; if the non-employee spouse smokes, the insurance premium charged to the employee will be raised significantly. ${ }^{62}$ The reality is that non-employees covered under an employer's health plan can incur just as much expense as employees. As employers look for creative solutions to rising costs, other companies are likely to follow the path of Weyco. A key question is how, and whether, nonemployees are distinguishable in any legally significant way from employees covered under the same employer health plan.

55. Michele L. Tyler, Note, Blowing Smoke: Do Smokers Have a Right? Limiting the Privacy Rights of Cigarette Smokers, 86 GeO. L.J. 783, 795 (1998) (citing HelEN HaLPIN

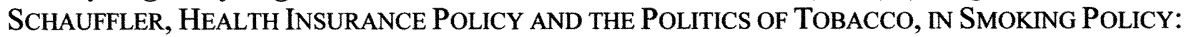
LAW, Politics, AND CULTURE (Robert L. Rabin \& Stephen D. Sugarman eds., 1993)).

56. Tyler, supra note 55, at 795 .

57. Id.

58. Id.

59. Id.

60. 60 Minutes Two (CBS television broadcast, July 16, 2006) (transcript on file with the author).

61. Id.

62. Severe Smoking Bans in Some Workplaces (CNN television broadcast, Dec. 9, 2005) (transcript on file with Author). 


\section{DisTINCTION BETWEEN THE EMPLOYEE AND THE EMPLOYEE'S SPOUSE OR DEPENDENT, WITH RESPECT TO HEALTH INSURANCE}

\section{A. The Nature of Employer-Sponsored Health Insurance}

Most private healthcare coverage is provided through employment, but this reality did not necessarily come about by design. ${ }^{63}$ Prior to the 1940 s, relatively few employers offered health insurance benefits to their employees. ${ }^{64}$ This changed, though, during World War II when government-enacted wage controls forced employers to entice employees by providing benefit packages, including health insurance, in lieu of higher wages. ${ }^{65}$ This practice became widespread and was even endorsed by the American Medical Association which had decided that private health insurance was preferable to the national public health insurance alternative being debated at the time. ${ }^{66}$ The federal government made changes to the tax code in 1954 to further support employersponsored health insurance; employers' contributions to employees' health insurance coverage were deductible by employers and excluded from taxable income for employees. ${ }^{67}$ Because health insurance was also a legally proper subject for collective bargaining purposes, the ties between health benefits and employment were solidified and an explosion in employment-based health insurance was released. ${ }^{68}$ In 1940, only twelve million people were enrolled in group hospital insurance plans; by 1955, the number had grown to 101 million. ${ }^{69}$

Employer-sponsored health insurance typically takes the form of group insurance. Some discussion of the basic parameters of group insurance helps put into context the benefits for employees and their spouses or dependents. Generally, group insurance refers to the coverage of a number of individuals through a single, comprehensive policy. ${ }^{70}$ Contract law defines a group insur-

63. Laura D. Hermer, Private Health Insurance in the United States: A Proposal for a More Functional System, 6 Hous. J. HEALTH L. \& PoL'y 1, 10 (2005) (citing Thomas Bodenheimer \& Kevin Grumbach, Paying for Healthcare, 272 JAMA 634, 636 (1994)). (1982)).

64. Id. (citing Paul StarR, Social TRANSFORMATION OF AMERICAN MEDiCine 290-334

65. Id. (citing Thomas Bodenheimer \& Kevin Grumbach, Paying for Healthcare, 272 JAMA 634, 636 (1994); PAUl STARR, SOCIAL TRANSFORMATION OF AMERICAN MEDICINE 311 (1982)).

66. Id. (citing Thomas Bodenheimer \& Kevin Grumbach, Paying for Healthcare, 272 JAMA 634, 636 (1994); PAUL STARR, SOCIAL TRANSFORMATION OF AMERICAN MEDICINE 280-89 (1982)).

67. Id. (citing John G. Day, Managed Care and the Medical Profession: Old Issues and Old Tensions - The Building Blocks of Tomorrow's Healthcare Delivery and Financing System, 3 CoNN. INS. L. J. 1, 15 n.50 (1996)).

68. Id.

69. Id. at 11. (citing Thomas Bodenheimer \& Kevin Grumbach, Paying for Healthcare, 272 JAMA 634, 636 (1994)).

70. 44A AM. JUR. 2D Insurance $§ 1828$ (2006) (citing Romano v. New Eng. Mut. Life 
ance policy as a contract between an insurer and an entity for the benefit of a group of people with some relationship to that entity. ${ }^{71}$ Group policies are typically interpreted as creating an insurance contract "between the employer and the insurer" intended to benefit individuals employed by the employer. ${ }^{72}$

Employees that obtain coverage through such group policies with their employers may have limited autonomy in choosing the type of coverage they desire. $^{73}$ The employer has primary responsibility for choosing a plan. ${ }^{74} \mathrm{~A}$ 2003 study showed that sixty-eight percent of all firms offering health insurance offered only one plan choice. ${ }^{75}$ The smaller the firm's size, the more likely the choice of plans will be limited. While "[s]ixty-nine percent of firms with fewer than 200 employees offered only one health insurance plan ... [only] $20 \%$ of firms with five thousand or more employees" restricted the choice to only one plan. ${ }^{76}$ In resonance with the theme of this Note, cost is the single largest factor determining which plan(s) an employer chooses to offer. ${ }^{77}$ The results of one study revealed that eighty percent of all firms surveyed cited cost as "very important" in determining which plan(s) to offer employees. ${ }^{78}$ On the other hand, only forty-five percent of firms questioned in another survey considered employee satisfaction with the plan to be "very important" in determining which plan(s) to offer. ${ }^{79}$ Even so, studies suggest employees are more confident in their employer's choice of health plans then they are in choosing a health plan themselves. ${ }^{80}$

Even with sometimes limited options in health plans, employers typically provide coverage for employees' dependents. The cost of such coverage, though, drives some employees to elect not to take advantage of the available health plans. ${ }^{81}$ Typically, employers pay the bulk of the individual coverage cost for their employees. ${ }^{82}$ However, employers often pay less for the dependent's insurance premiums then it will for the employee. ${ }^{83}$ The result is that an employee shoulders a far greater cost for dependent coverage than for her own

Ins. Co., 362 S.E.2d 334, 338 (W. Va. 1987)). 1999)).

71. Id. (citing In re: Louisiana Health Service and Idem. Co., 749 SO. $2 \mathrm{~d} 610,614$ (La.

72. Id. (citing Alsup v. Travelers Ins. Co., 268 S.W.2d 90, 94 (Tenn. 1954)).

73. Hermer, supra note 63, at 20.

74. Id.

75. Id. (citing Employer Health Benefits: 2003, ANN. SURVEY (Kaiser Fam. Found., Menlo Park, Cal.), 2003, at 64, available at http://www.kff.org/insurance /ehbs2003-abstract.cfm (last visited Mar. 14, 2008)).
76. Id.
77. Id.
78. Id.
79. Id.
80. Id. at 21 .
81. Id. at 19 .
82. Id. at $16-17$.

83. Id. at 20-21 (citing Paul Fronstin, EMP. Benefits Res. InSt., SourCes OF Health INSURANCE AND CHARACTERISTICS OF THE UNINSURED: ANALYSIS OF THE MARCH 2004 CURRENT POPULATION SURVEY 14 (2004)). 
coverage ${ }^{84}$ According to a 2005 study, six percent of all employers offering health insurance paid less than fifty percent of their employees' premiums. ${ }^{85}$ The cost shifting is even greater with smaller employers; thirty-five percent of employers with fewer than two hundred employees paid less than fifty percent of dependents' premiums. ${ }^{86}$

\section{B. Third Party Beneficiary Law}

Because employer-sponsored group health insurance policies are "construed as creating a contract of insurance between the employer and the insurer, [] for the benefit of the insured employees, ${ }^{, 87}$ third party beneficiary law is implicated in understanding the respective rights of employees and dependents regarding the insurance policy. The Restatement of Contracts provides that "a promise in a contract creates a duty in the promisor to any intended beneficiary to perform the promise, and the intended beneficiary may enforce the duty." 88 The intention of the parties to the contract is determinative; if the parties intended to benefit a third party through the contract, the third-party has rights as an intended beneficiary. ${ }^{89}$ So long as the third-party beneficiary is ascertainable, the contract need not name the beneficiary specifically. ${ }^{90}$ The beneficiary, as a member of a class of persons, may be recognized as a third-party beneficiary as long as the class is sufficiently described or designated. ${ }^{91}$ Although the beneficiary must be identified before she has an enforceable right as a third party beneficiary of a contract, she need not be identified or identifiable at the time the contract is made. ${ }^{92}$

The respective contractual rights of employees and their dependents, then, depend upon construction of the employer-sponsored healthcare policy. As previously stated, group health policies are usually construed as being a contract between the employer and the insurer for the benefit of the employee. Employees are third party beneficiaries of the policies; the construction of the contract clearly indicates that such policies are being interpreted as intended for

84. Id. at 20 .

85. Id. (citing Thomas Bodenheimer \& Kevin Grumbach, Paying for Healthcare, 272 JAMA 634, 636 (1994); PAUl STARr, SOCIAL TRANSFormation OF AMERICAN MEDICINE 311 (1982)).

86. Id.

87. 44A AM. JUR. 2D Insurance $\S 1828$ (2006) (citing Alsup v. Travelers Ins. Co., 268 S.W. 2d 90, 94 (Tenn. 1954)).

88. 17A AM. JUR. 2D Contracts $\S 440$ (2006) (citing Restatement (Second) of Contracts $\S$ $304(1981))$.

89. Id. at $\S 430$ (citing Hrushka v. State, Dep’t. of Pub. Works \& Highways, 381 A.2d 326,326 (N.H. 1977)).

90. Id. at $\S 443$ (citing MK W. Street Co. v. Meridien Hotels Inc., 184 A.D.2d 312, 312 (N.Y. App. Div. 1992)).

91. Id. at $\S 436$.

92. Id. at $\S 443$ (Associated Teachers of Huntington, Inc. v. Bd. of Educ., 306 N.E.2d 791, 791 (N.Y. 1973)). 
the benefit of employees. Indeed, the historical development of employersponsored health insurance gives witness to the fact that employers intentionally entered into contracts with insurers in order to provide health benefits that would entice employees to join their firms. As further enticement to employees, employers took advantage of the tax code to provide health coverage to employees' dependents. Absent specific language in an insurance contract between the employer and the insurer that states a different intention, employees and their dependents have the same standing with respect to employersponsored health insurance; all are third party beneficiaries.

\section{EMPLOYER CONTROL OF OFF-DUTY CONDUCT - LIFESTYLE DISCRIMINATION?}

\section{A. Employer Control of Off-Duty Employee Conduct}

With the reality of rising healthcare costs, finding ways to reduce or redistribute the burden of those costs is a legitimate employer interest. Making employees with unhealthy habits or risky behaviors pay higher premiums requires employers to discover those habits and behaviors. Employers exert at least indirect control over employees' off the job conduct through imposition of a policy for discovery which discourages employees from engaging in unhealthy habits and risky behaviors. Certainly, direct restrictions of employee behavior (e.g., on-duty and off-duty smoking bans) reflect employer control of off-duty employee conduct. Most reasonable people will agree that employers should be given latitude in imposing restrictions on employee on-duty behavior, but those same people may disagree as to the degree to which employers' interests should justify control over employees' off-duty behavior. ${ }^{93}$

Employers generally follow two approaches, often used in combination, to control off-duty conduct of employees in advance and to punish what the employer deems to be unacceptable off-duty conduct upon its occurrence. ${ }^{94}$ The first approach is to adopt and give notice of rules that specify what off-duty conduct is forbidden; these rules tend to be based on forecasts that the forbidden conduct is likely to lead to financial harm for the employer. ${ }^{95}$ The second strategy is to develop and utilize a more general policy stating that employees are forbidden from conduct that brings harm to or threatens to bring harm to the employer. ${ }^{96}$ The general policy statement is usually used to allow employers more discretion to protect their interests against unexpected events that might not be fully accounted for in a narrow rule forbidding specific conduct. ${ }^{97}$

93. Sugarman, supra note 27 , at 380.

94. Id. at 398 .

95. Id. at 398-99.

96. Id. at 399 .

97. Id. 
Without practical guidelines that give notice to employees of how a vague general policy is likely to be applied, it may be difficult for employees to avoid the very conduct about which the employer is concerned. ${ }^{98}$ The general policy approach also raises concern that the employer may wield unfettered discretion that risks unfair application of the policy. ${ }^{99}$

Employers may use various methods for discovering off-duty conduct of employees. The first and perhaps least invasive technique is self-reportingroutinely asking applicants and employees questions about off-duty conduct and/or instructing employees to come forward when certain conduct occurs. ${ }^{100}$ If applicants and employees are candid about their conduct, then self-reporting may allow employers to learn what they want to know directly. ${ }^{101}$ Further, if an employee provides false information on his application, the employer will have legitimate grounds for terminating the employee. A second strategy for discovering off-duty conduct is through indirect sources. If employees know disclosure of their off-duty conduct may jeopardize their job, they have incentive to not always be forthright. ${ }^{102}$ News accounts or tips from other employees or members of the general public provide indirect evidence of off-duty conduct. ${ }^{103}$ While the availability of indirect sources of information may seem to be more a matter of chance, employers might encourage the information by rewarding people who provide tips about observed conduct. ${ }^{104}$ Searching public and private records provides a third approach to discovery. ${ }^{105}$ Finally, employers may use systematic investigations to discover off-duty conduct: physical examinations by physicians, "paper and pencil" tests of propensity for honesty and/or psychological makeup, and blood, urine, saliva, and breath tests to discover drug use, tobacco use, cholesterol level, blood pressure, and other bodily conditions. ${ }^{106}$ The use of such screening devices brings the risk of high rates of false negatives; employees may be erroneously identified as having undesirable offduty conduct. ${ }^{107}$ Yet, employers may believe the risk is justified. ${ }^{108}$

Consider, for example, the issue of smokers who are refused employment out of employer fears of high healthcare costs. Although employee smokers as a group may make higher average claims on the firm's healthcare plan than would non-smokers hired in their place, a sub-

\footnotetext{
98. Id.

99. Id.

100. Id. at 400 .

101. Id.

102. Id.

103. Id.

104. Id.

105. Id. at $400-01$.

106. Id. at 401 .

107. Id.

108. Id.
} 
stantial proportion of employee smokers might not have higher healthcare claims than the average non-smoking employee who is hired instead. Indeed, smokers may be neglectful of their health and most may actually use healthcare services less than average (so long as they don't suffer from a grave illness). At the same time, a few smokers, not readily identifiable in advance, are likely to be very expensive. As a result ... an employer might conclude that the best and cheapest thing to do would [be] to simply tolerate all the false negatives and refuse jobs to all smokers. ${ }^{109}$

Clearly, the issues confronting employers seeking to discover the off-duty conduct of employees are especially complex when potentially life threatening behaviors like smoking are implicated.

\section{B. Lifestyle Discrimination Concerns.}

Company policies intended to address rising healthcare costs by refusing to hire or making employees pay for their unhealthy habits or risky behaviors may pose a threat to the privacy and autonomy of American workers. ${ }^{110}$

Between the hours of nine and five, the average person's life is not her own. Her employer can tell her what to do, and when and how to do it. Employers do not have to be polite, or fair. Even one's rights as an American citizen largely disappear when one goes through the office door. This situation is tolerable because it is limited to working hours. Few would want to live in a society in which they were subjected to employer control twenty-four hours a day.

But this is a very real possibility if employers are permitted to regulate off-duty behavior unrelated to job performance because of its health implication. ${ }^{111}$

Beyond the commonly cited vice of smoking, many other items consumed by workers pose health risks: caffeine, alcohol, red meat, and sugar. ${ }^{112}$ Recreational activities such as skiing, scuba diving, motorcycle riding, water sports,

109. Id.

110. Lewis L. Maltby \& Bernard J. Dushman, Whose Life is it Anyway - Employer Control of Off-Duty Behavior, 13 ST. LouIs U. PUB. L. REV. 645, 645-46 (1994).

111. Id. at 646.

112. Id. 
and others are risky behaviors as well. ${ }^{113}$ Sleeping habits, sexual activity, and the decision to have children all have health implications, too. "I14 "Indeed, there are few aspects of our lives that will be immune from employer control if this precedent is allowed to stand." 115

The United States Constitution's Bill of Rights and, by its extension to the states through the Fourteenth Amendment, is the basis for privacy rights and the prohibition of unwarranted intrusion. ${ }^{116}$ Employee privacy rights for private sector employers have developed through statute, case law and contract. ${ }^{117}$ "An employee's right to privacy is not completely suspended while at work, however, nor is an employer's right to control completely eliminated when an employee is away from work; rather, there is a shift in the privacy-versus-control balance." 118

A prominent scholar on privacy matters has suggested that those individuals favoring priority for employees' privacy rights may be divided into two groups, the fundamentalists and the pragmatists. ${ }^{119}$ Fundamentalists would support the strong presumption that employees' interests in their personal offduty autonomy have priority over employers' economic justifications for restrictions on employees' private lives. ${ }^{120}$ Pragmatists take a less absolutist approach, putting considerable weight on employees' interests to act as they wish during their off-duty time without consequences on the job. ${ }^{121}$ Pragmatists acknowledge employer interests but dislike adverse employer decisions based on off-duty behavior they consider to be insufficiently related to the employee's work. $^{122}$

How analogous is lifestyle discrimination to those categories of employment discrimination that are already widely agreed to be properly forbidden by the law, most importantly, discrimination on the basis of race, sex, national origin/ancestry, religion, age, and disability? $\cdots$

In the end, the key question may be whether we feel strongly enough that employers have an obligation to accommodate the employee's private time autonomy (in

113. Id.

114. Id.

115. Id.

116. Paul F. Gerhart, Employee Privacy Rights in the United States, 17 COMP. LAB. L. \& PoL'Y J. 175, 176 (1995).

117. Id.

118. Id. at 178.

119. Sugarman, supra note 27, at 408 (citing Alan F. Westin, Privacy in the Workplace: How Well Does American Law Reflect American Values?, 72 CHI.-KENT L. REV. 271, 272-73 (1996)).

120. Id.

121. Id. at 409 .

122. Id. 
the fashion that employers have a duty to accommodate the disabled, that is, even at an extra cost to the employer). In short, how strongly do we value privacy after all, and how wrong do we think it is for employers to run over this interest of workers? ${ }^{123}$

Comparing lifestyle discrimination with forbidden categories of employment discrimination is a valid consideration in defining privacy rights. It is not difficult to see a distinction, though, between a protected status concerning which the employee has no choice (e.g., race, gender, age) and a behavior choice (e.g., smoking).

\section{Extending Restrictions on Off-Duty Conduct to Spouses and Other Dependents of Employees}

The same interests that guide an employer to reduce or redistribute healthcare costs through policies that track, restrict, and/or impose penalties for offduty conduct of employees give incentive for employers to impose similar policies targeting unhealthy habits or risky behaviors of spouses and other dependents of employees covered under the same health plan. Assuming spouses and dependents of an employee covered under the employer's health plan have the same contractual rights as the employee under the plan, the imposition of restrictions or control over the non-employees' behaviors or habits poses similar concerns for lifestyle discrimination as are present for the employee. Additionally, employer policies targeting non-employees may present risks of a slippery slope: Does the imposition of such policies provide incentive for employers to gain information about non-employees not covered under the health plan (e.g., spouses or dependents who smoke and, therefore, contribute to the covered employee's health risks related to second-hand smoke)? Would such policies create incentive for employers to gain broad information about the covered beneficiaries' living environment (e.g., residing in an area that subjects beneficiary to more exposure to allergens or general pollution; residing in a neighborhood that is "less safe" than other neighborhoods)?

\section{PRotections AgAinst LIFESTYLE DisCRIMINATION}

Given the increasing trend of employers controlling off-duty conduct of employees and the pressures facilitating employers' control of health-related conduct of employees' dependents, what protections are in place or could be engaged to prevent discrimination and invasion of privacy? 


\section{A. Protections for Employees}

\section{State Protection}

There is no uniform consensus among the states as to whether a commonlaw right of privacy concerning employer-employee relationships should be acknowledged. ${ }^{124}$ But, two torts for invasion of privacy have emerged with respect to the off-duty conduct of employees: (1) unreasonable intrusion upon the seclusion of another and (2) unreasonable publicity given to another's private life. ${ }^{125}$

Discrimination against employees who use tobacco and other lawful products when off-duty has grabbed the attention of a larger group of the states. Thirty states and the District of Columbia have laws prohibiting discrimination against employees who smoke off-site, and thirteen states outlaw bans on offduty alcohol consumption. ${ }^{126}$ North Carolina and some other states include statutory exceptions for situations in which the use of these lawful products "adversely affects the employee's job performance or the person's ability to properly fulfill the responsibilities of the position in question or the safety of other employees." 127 These statutes reflect a willingness to balance the employee's right to use legal products against the employer's interest in controlling off-duty conduct of employees that could affect the workplace. ${ }^{128}$ These statutes provide some protection to employees. ${ }^{129}$ Because the scope of the statutes is limited to the use of certain products, though, many facets of the employee's off-duty life remain unprotected. ${ }^{130}$

Four states - Colorado, North Dakota, California, and New York - have enacted statutes that provide protection for a broader range of off-duty conduct. ${ }^{131}$ Each of these statutes has serious limitations, though, on the protections actually afforded to employees. ${ }^{132}$ Colorado's statute protects "any lawful activity" of the employee done while off-duty, but the protection extends only to current employees. ${ }^{133}$ Because the statute does not address prospective employees, the law may facilitate the unintended consequence of promoting dis-

124. Rives, supra note 46, at 556 (citing Pauline T. Kim, Privacy Rights, Public Policy, and the Employment Relationship, 57 Оноо ST. L.J. 671, 672 (1996)).

125. Id. (quoting Marisa Anne Pagnattaro, What Do You Do when You Are Not at Work?: Limiting the Use of Off-Duty Conduct as the Basis for Adverse Employment Decisions, 6 U. PA. J. LAB. \& EMP. L. 625, 631 (2004)).

126. Id. at 558 (quoting Kim Norris, His Ultimatum: Quit Smoking or Lose Job, DETROIT Free PrEss, Feb. 15, 2005, at 1A).

127. Id. (citing N.C. GEN STAT. § 95-28.2(b) (2003)).

128. Id. (quoting Pagnattaro, supra note 125, at 642).

129. Id.

130. Id.

131. Id. at 559 (quoting Pagnattaro, supra note 125, at 646).

132. Id.

133. Id. (citing Colo. ReV. STAT. § 24-34-402.5(1)). 
crimination in hiring decisions. ${ }^{134}$ North Dakota's statute prohibits discrimination for an employee or prospective employee's "participation in lawful activity off the employer's premises during nonworking hours which is not in direct conflict with the essential business-related interests of the employer." 135 But, an employee's lawful activity will not be protected under the statute if the activity is "contrary to a bona fide occupational qualification that reasonably and rationally relates to employment activities." 136 In interpreting North Dakota's statute, courts have been troubled by the ambiguous "lawful activity" language of the statute. ${ }^{137}$ For example, in Hougum v. Valley Memorial Homes, the court struggled with the meaning of "lawful."138 In that suit, the plaintiff brought a claim against the residential home where he worked as a chaplain after he was fired for allegedly masturbating in the stall of a department store restroom. ${ }^{139}$ While the chaplain argued that his conduct was a lawful activity, the court declined to hold whether the activity qualified as "lawful." " 140 In his partially dissenting opinion, Chief Justice Vande Walle expressed that he did not believe the statute "intended to protect as lawful activity off the employer's premises during nonworking hours sexual activity, alone or with others, in a bathroom in a store in a shopping mall."141 The ambiguous language of the statute leaves uncertainty as to the type of conduct for which a North Dakota employee can be fired. ${ }^{142}$ Likewise, the laws enacted in California and New York have also been restricted by narrow construction of statutory language which, on its face, seems to provide broad protections for employee's off-duty conduct. ${ }^{143}$

\section{Federal Protection}

While no federal statute explicitly protects employees from employer discipline for off-duty conduct, several statutes protect facets of employees' personal lives from undue scrutiny. ${ }^{144}$ Four statutes limit the use of off-duty conduct in connection with adverse employment decisions: the Immigration Reform and Control Act; the Fair Credit Reporting Act; Title VII of the Civil Rights Act; and the Employee Polygraph Protection Act. ${ }^{145}$ Additionally, the

134. Id. (quoting Jessica Jackson, Colorado's Lifestyle Discrimination Statute: A Vast and Muddled Expansion of Traditional Employment Law, 67 U. CoLo. L. REV. 143, 143 n.5 (1996)).

135. Id. at 560 (citing N.D. CENT. CODE § 14-02.4-01, -03 (2004)).

136. Id. (citing N.D. CENT. CODE § 14-02.4-08 (2004)).

137. Id. at 561 .

138. Id. (citing Hougum v. Valley Mem'l Homes, 574 N.W. 2d 812, 821-22 (N.D. 1998)).

139. Id. (citing Hougum, 574 N.W. 2 d at 815 ).

140. Id. (citing Hougum, 574 N.W. 2 d at 820-22).

141. Id. (citing Hougum, 574 N.W. $2 \mathrm{~d}$ at 823 (Vande Walle, C.J., concurring in part and dissenting in part)).

142. Id.

143. Id. at 561-63.

144. Pagnattaro, supra note 125 , at 670 .

145. Id. The Immigration and Control Act prevents the employment of unlawful aliens, but also protects prospective employees who want to restrict employers from delving into their 
Employee Retirement Income Security Act and the Health Insurance Portability and Accountability Act provide protections against employee discrimination, related particularly to the provision of healthcare benefits.

\section{a. Employee Retirement Income Security Act of 1974 ("ERISA”)}

Under section 510 of ERISA, employers are expressly prohibited from disciplining or terminating an ERISA employee benefit plan participant "for the purpose of interfering with the attainment of any right to which such participant may become entitled" under an ERISA employee benefit plan. ${ }^{146}$ Under this rule, an employer may not terminate a plan participant merely because the employee incurs higher healthcare costs, relative to other employees, under the employer's health insurance program. ${ }^{147}$ It is not clear, though, whether ERISA protects prospective employees who engage in risky behaviors such as smoking. ${ }^{148}$ Recent case law suggests that ERISA section 510 does not protect job applicants. ${ }^{149}$

\section{b. Health Insurance Portability and Accountability Act of 1996 ("HIPAA")}

The preamble to HIPAA describes that the intent of the Act is "to improve portability and continuity of health insurance coverage ... to combat waste, fraud, and abuse in health insurance and healthcare delivery, to promote the use of medical savings accounts, to improve access to long-term care services and coverage, to simplify the administration of health insurance, [etc.]." ${ }^{150}$ HIPAA added sections to both ERISA and the Public Health Service Act that prohibit group health plans from discriminating against individual participants or beneficiaries based on any health factor of such participants or beneficiaries. ${ }^{151}$

backgrounds beyond what is necessary to comply with the law. Id. (citing Immigration Reform and Control Act of 1986, 8 U.S.C. $\$ \S 1324 a$ (d)(2)(C), (D) (2000)). The Fair Credit and Reporting Act protects current and prospective employees' private lives by requiring employers to comply with notice provisions of the Act. Pagnattaro, supra note 125, at 670-71 (citing Fair Credit Reporting Act of 1996, 15 U.S.C. § 1681 (1993)). Title VII protects employees' off-duty associational privacy. Pagnattaro, supra note 125, at 671 (citing Title VII of the Civil Rights Act of 1964, 42 U.S.C. $§ 2000$ e (2003)). The Employee Polygraph Protection Act limits the use of polygraph tests to protect employees from employers who might abuse the test to seek information beyond the scope of the employment responsibilities. Pagnattaro, supra note 125, at 671 (citing Employee Polygraph Protection Act, 29 U.S.C. § 2002 (1999)).

146. Steven J. Friedman \& Lisa C. Chagala, Penalizing Applicants and Employees For Smoking: A Potential Smoking Gun?, EMPLOYMENT \& LABOR UPDATE, Sept. 2006, available at http://www.lorman.com/newsletters/article.php?article_id=506\&newsletter_id=109\&category_i $\mathrm{d}=1$ \&topic=LB (citing Employee Retirement Income Security Act, 29 U.S.C. $\$ 1140$ (2004)) (last visited Mar. 14, 2008).

147. Id.

148. Id.

149. Id.

150. Health Insurance Portability and Accountability Act of 1996, Pub. L. No. 104-191, 110 Stat. 1936 (codified in scattered sections of 26, 29 and 42 U.S.C.).

151. Nondiscrimination and Wellness Programs in Health Coverage in the Group Market, 
Under regulations released pursuant to HIPAA, "health factors" include: health status, medical condition (including both physical and mental illness), claims experience, receipt of healthcare, medical history, genetic information, evidence of insurability, and disability. ${ }^{152}$ Notably, the regulation's definition of "evidence of insurability" incorporates participation in activities such as motorcycling, snowmobiling, all-terrain vehicle riding, horseback riding, and skiing $^{153}$; thereby, prohibiting discrimination based upon beneficiaries' participation in such activities. "Group health plans or issuers are not required to provide coverage for any particular benefit to any group of similarly situated individuals." 154 Benefits provided and any restrictions on benefits, however, must be applied uniformly to all similarly situated individuals; restrictions must not be directed at individual participants or beneficiaries based on any health factor of the participants or beneficiaries. ${ }^{155}$

Generally, employers offering a group health plan may not require an individual, as a condition of enrollment or continued enrollment under the plan, to pay a premium or contribution that is greater than the premium or contribution for a similarly situated individual enrolled in the plan based on any health factor relating to the individual or a dependent of the individual. ${ }^{156}$ An important exception exists, however, to accommodate wellness programs. ${ }^{157}$ Any program designed to promote health or prevent disease qualifies as a wellness program. ${ }^{158}$ Many employers encourage participation in wellness programs to drive down health costs by offering rewards to participants, such as reduced healthcare premium contributions. An estimated 30,000 plans covering 1.1 million participants vary employee premium contributions across similarly situated individuals due to participation in a wellness program that provides rewards based on satisfaction of a health factor-related standard. ${ }^{159}$ Research suggests that well-designed wellness programs can deliver benefits well in excess of their costs. ${ }^{160}$ The U.S. Centers for Disease Control and Prevention es-

71 Fed. Reg. 75,014 (Dec. 13, 2006) (to be codified 29 C.F.R. pt. 2590).

152. Id. at 75,038 .

153. Id.

154. Id. at 75,014 .

155. Id. at $75,014-015$.

156. Id. at 75,041 .

157. The interim rules and proposed regulations for HIPAA referred to programs of health promotion and disease prevention allowed under this exception as "bona fide wellness programs." Id . at 75,017 . The final regulations have dispensed with the term "bona fide" with respect to wellness programs and, in its place have added a description of wellness programs that do not have to satisfy additional requirements in order to comply with nondiscrimination requirements. $I d$. Comments received from the release of the proposed regulations suggested that the use of the term "bona fide" fostered confusion because some programs that are not "bona fide" within the narrow meaning of the proposed rules nonetheless satisfy the HIPAA nondiscrimination requirements. Id. The final regulations treat all programs of health promotion or disease prevention as wellness programs and specify which of those wellness programs must satisfy additional standards to comply with the nondiscrimination requirements. Id.

158. Id. at 75,043 .

159. Id. at 75,027 .

160. Id. 
timate that implementation of a proven clinical smoking cessation program can save one year of life for each $\$ 2587$ invested. $^{161}$

A wellness program that does not make receipt of a reward conditioned on an individual satisfying a health factor-related standard does not violate HIPAA regulations, so long as the program is available to all similarly situated individuals. ${ }^{162}$ A wellness program that conditions receipt of a reward on satisfaction of a health factor-related standard is not in violation of HIPAA regulations if the program satisfies five requirements: ${ }^{163}(1)$ the reward for the wellness program may not exceed twenty percent of the cost of coverage under the plan; ${ }^{164}$ (2) the program must be reasonably designed to promote health or prevent disease ${ }^{165}(3)$ the program must give eligible individuals the opportunity to qualify

161. Id. (citing J. Cromwell et al., Cost-Effectiveness of the Clinical Practice Recommendations in the AHCPR Guideline for Smoking Cessation, 278 JAMA 1759, 1759-66 (1997)). tions:

162. Id. at 75,044 . The following example programs would not violate the HIPAA regula-

(i) A program that reimburses all or part of the cost for memberships in a fitness center; (ii) A diagnostic testing program that provides a reward for participation and does not base any part of the reward on outcomes; (iii) A program that encourages preventive care through the waiver of the copayment or deductible requirement under a group health plan for the costs of, for example, prenatal care or well-baby visits; (iv) A program that reimburses employees for the costs of smoking cessation programs without regard to whether the employee quits smoking; (v) A program that provides a reward to employees for attending a monthly health education seminar."

Id.

163. Id.

164. Id. Specifically,

The reward for the wellness program, coupled with the reward for other wellness programs with respect to the plan that require satisfaction of a standard related to a health factor, must not exceed twenty percent of the cost of employee-only coverage under the plan. However, if, in addition to employees, any class of dependents (such as spouses or spouses and dependent children) may participate in the wellness program, the reward must not exceed twenty percent of the cost of the coverage in which an employee and any dependents are enrolled.... [T] he cost of coverage is determined based on the total amount of employer and employee contributions for the benefit package under which the employee is (or the employee and any dependents are) receiving coverage. A reward can be in the form of a discount or rebate of a premium or contribution, a waiver of all or part of a cost-sharing mechanism (such as deductibles, copayments, or coinsurance), the absence of a surcharge, or the value of a benefit that would otherwise not be provided under the plan.

Id.

165. Id. The standard does not require scientific proof that the method used promotes wellness; the intent is to allow experimentation in diverse ways of promoting wellness. Id. at 75,018. This standard is met if the program has a reasonable chance of improving the health of or preventing disease in participating individuals, is not overly burdensome, and "is not a subterfuge for discriminating based on a health factor, and is not highly suspect in the method chosen to promote health or prevent disease." Id. at 75,044 . 
for the reward at least once per year; ${ }^{166}$ (4) the reward must be available to all similarly situated individuals; ${ }^{167}$ and (5) the plan or issuer must disclose the availability of a reasonable alternative standard, or the possibility of waiver of the otherwise applicable standard. ${ }^{168}$

\section{c. Proposed federal legislation}

Some advocates argue that the time has come for new federal legislation to ensure appropriate levels of protection for the off-duty conduct of employees while balancing employers' legitimate interests. State statutes or constitutional amendments that recognize employee privacy rights but are framed in language requiring consistent court interpretation for enforcement provide inadequate protection for employees and leave uncertainties as to the scope of employee privacy rights. ${ }^{169}$ In addition, the realities of a global economy and multistate employers make it difficult for employers to develop and implement employment practices that are compliant with the variable degrees of employee protection afforded by individual state statutes. ${ }^{170}$

166. Id. In the earlier proposed HIPAA rules, the requirement that a program give individuals the opportunity to qualify for the reward at least once per year was deemed indicative that the program was "reasonably designed to promote good health or prevent disease." Id. at 75,018 . As proposed, the once per year requirement was intended to establish a bright-line standard for determining the minimum frequency that is consistent with a reasonably designed program. Id. A wide range of factors, however, could affect the reasonableness of the design of a wellness program. A program that imposes an overly burdensome time commitment or a requirement to engage in illegal behavior, for example, might not be reasonably designed. $I d$.

167. Id. at 75,044. A reward is not deemed to be available to all similarly situated individuals unless the program allows a reasonable alternative standard (or waiver of the otherwise applicable standard) for obtaining the reward: (1) for any individual for whom it is unreasonably difficult due to a medical condition to satisfy the otherwise applicable standard, and (2) for any individual for whom it is medically inadvisable to attempt to satisfy the otherwise applicable standard. Id. The specific alternative standard need not be established prior to commencement of the program; it is sufficient to determine a reasonable alternative standard once a participant gives notice of one of the qualifying conditions that prevents satisfaction of the otherwise applicable standard. $I d$. at 75,019 . Employers are entitled to seek verification, such as a statement from an individual's physician that a health factor makes it unreasonably difficult or medically inadvisable for the individual to satisfy or attempt to satisfy the otherwise applicable standard. Id. at 75,044 .

168. Id. All plan materials describing the terms of the program must disclose the availability of an alternative standard. $I d$. However, if the plan materials provide only a general mention that a program is available, without detailing the terms of the program, this disclosure is waived. $I d$. The following sample language would satisfy this disclosure requirement:

If it is unreasonably difficult due to a medical condition for you to achieve the standards for the reward under this program, or if it is medically inadvisable for you to attempt to achieve the standards for the reward under this program, call us at [insert telephone number] and we will work with you to develop another way to qualify for the reward.

Id.

169. Rives, supra note 46, at 563-64 (citing Pauline T. Kim, Privacy Rights, Public Policy, and the Employment Relationship, 57 Оніо ST. L.J. 671, 709 (1996)).

170. Id. at 564 (citing Laura B. Pincus \& Clayton Trotter, The Disparity Between Public 
At the heart of any effective legislation must be a balancing of employees' rights against legitimate interests of employers.

[Employers should not] be forced to swallow all of the financial costs associated with their employees' off-duty lifestyle choices, such as higher life and health insurance premiums. If an employee chooses to engage in a highrisk activity, such as smoking, it does not automatically follow that an employer should bear all of the additional financial costs associated with that choice. The division of costs between employer and employee, however, must be set out carefully; an employer should not be able to raise an employee's premiums so high as to make the supposedly protected off-duty activity cost prohibitive. ${ }^{171}$

The following statute, based in part on New York and North Carolina statutes, has been proposed to balance employee rights and employer interests while filling gaps seen in some state statutes: ${ }^{172}$

1) Unless otherwise provided by law, it shall be unlawful for any employer or employment agency to refuse to hire, employ or license, or to discharge from employment or otherwise discriminate against an individual in compensation, promotion or terms, conditions or privileges of employment because of:

a) an individual's political activities outside of working hours, off of the employer's premises, and without use of the employer's equipment or other property, if such activities are legal;

b) an individual's legal use of consumable products prior to the beginning or after the conclusion of the employee's work hours, off of the employer's premises, and without use of the employer's equipment or other property;

c) an individual's legal recreational activities outside of work hours, off of the employer's premises, and without use of the employer's equipment or other property. These activities include but are not limited to: sports, games, hobbies, exercise, reading, and the viewing of television, movies, and similar material;

d) an individual's membership in a union; or

and Private Sector Employee Privacy Protections: A Call for Legitimate Privacy Rights for Private Sector Workers, 33 AM. Bus. L.J. 51, 54-55 (1995)).

171. Id.

172. Id. 
e) an individual's personal relationships, romantic or otherwise, including those with fellow employees.

2) It is not a violation of this section for an employer to:

a) restrict the lawful use of lawful products by employees during nonworking hours if the restriction relates to a bona fide occupational requirement and is reasonably related to the employment activities. If the restriction reasonably relates to only a particular employee or group of employees, then the restriction may only lawfully apply to them;

b) restrict the lawful use of lawful products by employees during nonworking hours if the restriction relates to the fundamental objectives of the organization; or

c) discharge, discipline, or take any action against an employee because of the employee's failure to comply with the requirements of the employer's substance abuse prevention program or the recommendations of substance abuse prevention counselors employed or retained by the employer.

3) This section shall not prohibit an employer from offering, imposing, or having in effect a health, disability, or life insurance policy distinguishing between employees for the type or price of coverage based on the use or nonuse of lawful products if:

a) differential rates assessed by employees reflect actuarially justified differences in the provision of employee benefits;

b) the employer provides written notice to employees setting forth the differential rates imposed by insurance carriers; and

c) the employer contributes an equal amount to the insurance carrier on behalf of each employee of the employer. ${ }^{173}$

Notably, section 1 of the proposed statute provides broad protection for employees, while identifying specific categories of rights to serve as guidelines for employers and employees. The reference in section 1(b) to "consumable products" covers not only the typical alcohol and tobacco products, but also provides protection for employees against discrimination based on food consumption or its effects, such as obesity. ${ }^{174}$ But section 2(b) would allow 
employers to restrict employees' consumption of those lawful products if the conduct interfered with the organization's fundamental objectives. ${ }^{175}$ While this would allow an organization with a fundamental objective of cancer prevention to restrict smoking, the same would not be true of the Weyco, Inc. example used earlier; Weyco's objective is to administer healthcare plans, not prevent cancer. ${ }^{176}$ Section three strikes to the heart of the employer strategy of making employees pay for their riskier behaviors or habits to reduce healthcare costs. The statute would not disallow distinctions between employees for their use of lawful products, but the employer would need to justify those distinctions and make equal premium contributions for all employees.

\section{B. Protection for Employees' Spouses and Dependents}

The nature of the employer-employee relationship implies important duties and rights between the two that provide a backdrop for protections afforded to the interests of employees. Employees covered under an employer's health plan typically give a substantial amount of their waking hours to their responsibilities as an employee. Employers invest substantial resources into training and retaining quality workers. The protections that have been put in place for employees arose out of the give-and-take of the employment relationship.

The nature of the relationship between the employer and the employees' dependents is not the same. Voluntary participation in an employer's health plan may be the only legally significant connection between an employer and the employees' dependents. Employers are not required to offer such health coverage, and the participation of employees' dependents is voluntary. While employers need not provide health coverage, once they do they are bound to keep their practices in compliance with existing protections for employees. HIPAA provides protection to employees' dependents because they are beneficiaries of an employer health plan. Wellness programs provide a logical platform by which employers could invade into information about beneficiaries' health habits. Accordingly, HIPAA's restrictions on the operation of wellness programs and their relationship to incentives in health coverage provide some protection for employees and other beneficiaries, alike. ${ }^{177}$

Effective protections for employees and their dependents do not come without an impetus for change. As with all change, civic will must coalesce in order to bring about changes in public policy. Specific cases of invasions of privacy that bring the attention of the media and foster public debate can help bring about discussions, but often more is needed. ${ }^{178}$ To the degree that the labor market allows employers to be pickier about their hiring, employers could use off-work conduct as more of a factor in their hiring and firing of em-

175. Id. at 566 .

176. Id.

177. See supra notes 151-164 and accompanying text.

178. Sugarman, supra note 27 , at 437 . 
ployees. ${ }^{179}$ This, in turn, could draw more attention to employers' focus on what people are doing in their personal lives. Loss of privacy in other areas could also prompt people to speak out about employer practices that infringe on the personal lives of employees and their dependents. ${ }^{180}$ Reportedly, many in the human resources field sympathize with the importance of maintaining privacy; this could make employers who engage in lifestyle discrimination appear to be at odds with dominant social norms. ${ }^{181}$

\section{AlTERNATIVES FOR HEALTHCARE COST CONTAINMENT}

Employers and employees both have interests in containing the high cost of health insurance. The question is whether the existing framework of healthcare plans provides any alternatives that could contain costs while protecting against invasions of privacy rights.

\section{A. Evolution of Healthcare Plans}

The traditional indemnity health insurance plans of the past have all but disappeared. ${ }^{182}$ Traditional indemnity health insurance permitted an individual to choose any healthcare provider, and the insurer would cover the majority (usually eighty percent) of the provider's fee, with the insured making up the difference out-of-pocket. ${ }^{183}$ Managed care has been the norm for some time and appears to have played a significant role during the $1990 \mathrm{~s}$ in curtailing the rise in health insurance premium costs. ${ }^{184}$ Although managed care plans have been part of common vernacular since at least the late 1980s, a 2001 study found that while about ninety percent of workers who obtained health coverage through employment were enrolled in a managed care plan, about forty-seven percent of those actually enrolled in a managed care plan reported never being in one. ${ }^{185}$

Managed care organizations ("MCOs") bring together the functions of care delivery and care reimbursement in an effort to control costs and healthcare utilization. ${ }^{186}$ Through MCOs, coverage is usually granted only for services rendered by a particular group or network of providers. ${ }^{187}$ Reimbursement

179. Id.

180. Id.

181. Id.

182. Hermer, supra note 63, at 21 (citing Employer Health Benefits-2005, ANN. SURVEY (Kaiser Fam. Found., Menlo Park, Cal.), 2005 at 68, available at http://www.kff.org/ insurance/7315/upload/7315.pdf).

183. Id. at 21-22.

184. Id. at 22 .

185. Id. (citing Managed Care Confusion, HeAlTH CONFIDENCE SuRVEY (Emp. Benefit Res. Inst., WASHINGTON, D.C.), Oct. 2001, available at: http://www.ebri.org/pdf/surveys/hcs/ 2001/mncr-fs.pdf).

186. Id.

187. Id. 
for services provided is determined by a scheme devised by the MCO and agreed to by the provider, with the intent to encourage cost-effective care. ${ }^{188}$ Integrating care within a network is intended to accomplish two goals: (1) to provide high quality care while reducing incentives to "over-utilize medical services ${ }^{189}$; and (2) to maximize marketplace forces, such as volume and discounting arrangement with providers and hospitals. ${ }^{190}$

Because of the perceived efforts of MCOs to interfere with physicians' methods of practicing medicine and their business practices, physicians lobbied fervently - and successfully for many decades - against the creation of MCOs at the state level. ${ }^{191}$ Any substantial barriers to the development of MCOs were overcome, though, when federal government enacted legislation in 1973 to encourage the formation of health maintenance organizations ("HMOs"). ${ }^{192}$ In response to growing healthcare costs, the legislation preempted state laws that discouraged or prohibited HMO formation. ${ }^{193}$

Several types of MCOs exist: HMOs, preferred provider organizations ("PPOs"), and point of service ("POS") plans. ${ }^{194}$ Generally, HMOs are organized as prepaid healthcare systems delivering healthcare exclusively through a network of healthcare providers in exchange for monthly premiums or other predetermined payments. ${ }^{195}$ HMO subscribers typically choose a primary care physician who serves as a "gatekeeper" for additional services, such as referral to a specialist. ${ }^{196}$ The specialist must be in the network for reimbursement; outof-network care is generally not covered. ${ }^{197}$ Additionally, any procedures or hospitalizations must receive preauthorization by the HMO to be eligible for reimbursement. ${ }^{198}$ The second MCO form is the PPO. PPOs can be described as networks of healthcare providers who agree to reductions in their usual feefor-service rates in exchange for incentives insurers provide to patients to make use of in-network care. ${ }^{199}$ PPO subscribers receive discounted care, as long as they are seen by a physician within the network. ${ }^{200}$ Unlike HMOs, PPOs usually do not require a primary care physician referral for specialist visits, but subscribers may pay higher out-of-pocket expenses due to PPOs' reliance on copayments and deductibles. ${ }^{201}$ Some consumers prefer the flexibility in physi-

188. Id. (citing Day, supra note 67, at 7).

189. Id. (citing Day, supra note 67, at 8).

190. Id. at 22-23. (citing Day, supra note 67 , at 8 ).

191. Id. at 23 .

192. Id. (citing Paul Starr, Social Transformation OF AMERican MEdicine 290-334 (1982)).

193. Id. (citing Day, supra note 67 , at 21 ).

194. Id. at 24-6.

195. Id. at 24 .

196. Id.

197. Id.

198. Id.

199. Id. at 25 .

200. Id.

201. Id. 
cian choice and healthcare utilization offered by PPOs over HMOs, despite the potential for higher out-of-pocket expenses. ${ }^{202}$ Finally, POS plans function much like HMOs. ${ }^{203}$ Like in HMOs, POS subscribers may see physicians within the managed care provider network, but they may also exercise an option to receive out-of-network care. ${ }^{204}$ Using a provider outside of the network, though, may come at the cost of significantly higher out-of-pocket expenses than the subscriber would have paid for in-network care. ${ }^{205}$

\section{B. Alternative Cost-Cutting Strategies}

In the wake of criticism for a number of their cost control measures, MCOs have embraced several different strategies intended to help reduce costs for employers while keeping their own profits at a healthy level. ${ }^{206}$ One commentator has identified three such strategies being utilized by MCOs: (1) loosening their control over health coverage decisions; (2) creating different levels of coverage (e.g., an enrollee pays less for in-network care and more for out-ofnetwork care); and (3) offering "consumer-driven health plans," in which employees are given greater choice in choosing a health plan and assume more financial responsibility (e.g., choosing a high-deductible plan in conjunction with a health savings account option). ${ }^{207}$ The third strategy, in particular, seems likely to become widespread. ${ }^{208}$

With the renewed rapid inflation of health insurance costs, the federal government ... has sought new methods of cost containment, largely in the form of "consumer directed" healthcare. The drafters of recent legislation and rules in this regard appear to have largely subscribed to the theory that, by reducing "moral hazard" in health insurance, we can help reduce healthcare costs. "Moral hazard" in the sphere of health insurance refers to the theory that those who are insured tend to incur greater costs with respect to it, due to the very fact that they do not have to pay for those costs out of pocket, or are only responsible for a fraction of them. Proponents of consumer directed healthcare therefore assume that, if individuals are made to be more responsible for

202. Id. at 25-26 (citing Day, supra note 67, at 22-3).

203. Id. at 26 .

204. Id.

205. Id.

206. Id. at 40 .

207. Id. (citing John V. Jacobi, After Managed Care: Gray Boxes, Tiers and Consumerism, 47 ST. LouIS U. L. J. 397, 401-06 (2003)).

208. Id. at 41 . 
the costs of the healthcare they consume, they will make more prudent choices with respect to it. ${ }^{209}$

The strategies being used by MCOs may hold potential for impacting healthcare costs for employers, but it is less clear how cost savings would be realized by employees. One expert suggests the employer-based health insurance system is more fundamentally flawed and calls for an economic response to revamp competition among healthcare delivery systems. ${ }^{210}$ Certainly, the potential benefits of plans for universal health coverage have been much debated in political discourse. ${ }^{211}$ Any plan for cutting healthcare costs must, however, address a reality of primary importance:

$[\mathrm{P}]$ atients of all incomes need timely and competent medical attention from both generalists and specialists without having to withstand bureaucratic battles at the same time as they are coping with illness or injury. They need to be able to expect their plan to deal with them in good faith concerning the benefits that their policies say they are supposed to receive. They also need timely and competent primary care. ${ }^{212}$

In short, patients must be able to rely on the quality and timeliness of the medical care provided by their insurance plans.

\section{CONCLUSION}

Health insurance costs generally have been on the rise for the last several decades. ${ }^{213}$ Cost escalation is not a new phenomenon. Whether by design, or historical accident, employment and access to the healthcare system have become intrinsically linked in the United States. As a result, employers do much more than facilitate industry and provide a forum for workers to establish vocations and earn wages. Employers represent the gateway through which countless employees and their families access vital healthcare services.

For some time, employers have contained costs associated with providing health insurance for employees by avoiding or limiting those costs through selective hiring and shifting costs to employees who engage in unhealthy behav-

209. Id.

210. See Alain C. Enthoven, Employment-Based Health Insurance is Failing: Now What?, W3 HEALTH AFF., WEB EXCLUSIVE 237 (May 28, 2003), available at: http://content.healthaffairs. org/cgi/reprint/hlthaff.w3.237v1?maxtoshow=\&HITS=10\&hits=10\&RESULTFORMAT=\&auth orl=enthoven \&andorexactfulltext=and\&searchid=1\&FIRSTINDEX=0\&resourcetype $=$ HWCIT (last visited Mar. 14, 2008).

211. See Hermer, supra note 63 , at 57-82.

212. Id. at 53 .

213. Id. at 13-16. 
iors. Now, employers are looking to realize savings by shifting costs to employees' dependents that practice unhealthy or risky behaviors. As equal beneficiaries, employees and dependents have the same contractual rights with respect to the employer's health insurance plan. Employer practices that restrict or pry into the personal lives of employees and their dependents raise legitimate concern of infringement of privacy rights. In response, limited employee protections have been put in place at the state and federal levels.

The reality is that the employment relationship is unique, different from, and more substantial than the relationship between the employer and the employees' dependents. Until a clarion alarm is raised against employer invasions of the privacy of employees' dependents, the requisite civic will is not likely to be raised to bring about changes in public policy to provide specific protections for this class of beneficiaries.

Employers, employees, and their dependents all have a vested interest in finding solutions to the problem of making health insurance affordable. Alternatives that generate savings by simply shifting costs from one side of the equation to the other are not generating true savings. At the same time, onus must be placed on individuals who knowingly engage in risky or unhealthy behaviors; those who take the risks must understand that higher healthcare costs may be a consequence of their actions. Fundamental changes to the healthcare system, such as efforts to give healthcare consumers more choice - and more responsibility - or the implementation of universal healthcare coverage could significantly change the nature of employment-based health insurance. In the end, in balancing all of these factors, the critical judgment may boil down to what we place more value on as a society: lower cost healthcare or fewer restrictions on personal freedoms. 
